\title{
Effect of rock weathering, clay mineralogy, and geological structures in the formation of large landslide, a case study from Dumre Besei landslide, Lesser Himalaya Nepal
}

\author{
Amar Deep Regmi ${ }^{1}$, Koki Yoshida ${ }^{1}$, Megh Raj Dhital ${ }^{2}$ and Krishna Devkota ${ }^{3}$ \\ ${ }^{1}$ Department of Geology, Faculty of Science, Shinshu University, Asahi 3-1-1, Matsumoto \\ 3908621, Japan \\ ${ }^{2}$ Central Department of Geology, Tribhuvan University, Kirtipur, Nepal \\ ${ }^{3}$ Department of Geology, Kyungpook National University, 1370 Sankyuk-dong, Bukgu, Degu \\ 702-701, South Korea
}

Abstract

The Dumre Besi landslide is one of the largest and most problematic failures on the MuglingNarayanghat Highway in central Nepal. Though it was triggered by the monsoon rain of 2003, geological structures and rock weathering have played a key role in its initiation and further aggravation. The slide is also controlled to some extent by the groundwater and rugged topography with high slope angles. The landslide zone comprises thinly laminated light grey siltstone with numerous crosscutting quartz veins, grey metasandstone (quartzite), bluish grey to white phyllite, black carbonaceous slate, and dolomite. A thrust fault passes through the center of the landslide, creating a thick deposit of loose, weathered rock material, and the fault has developed a very thick shattered zone where weathering is very intense. Using field and laboratory analyses, the rocks in the landslide zone can be divided into five zones based on the severity of weathering: none, slight, moderate, severe, and complete. Laboratory analyses showed that the chemically weathered rocks are significantly rich in smectite and vermiculite. Out of these, smectite is the most critical one, as it swells when wet. The formation mechanism of the clay minerals was analysed by various techniques, including X-ray diffraction, X-ray fluorescence, and thin-section analysis, and it was found that most of them were derived from weathering of rock. The clay minerals significantly reduced the rock strength and facilitated the extensive failure of Dumre Besi. The wide fault zone with deeply weathered and clay-rich debris is also responsible for the formation of debris flows in the monsoon season.

Keywords: Landslide, Himalaya, Weathering, Clay minerals 


\section{Introduction}

The study of landslides and related phenomena is an emerging interdisciplinary field in Nepal, and a relatively small amount of work has been accomplished so far. There is extensive literature on the study of landslide hazard mapping from Nepal Himalaya (e.g., Brundsen et al. 1975; Kojan1978; Wagner1981; Kienholz et al. 1983, 1984; Deoja et al. 1991; Dhital et al.1991; Dangol et al.1993; Dangol 2000; Dahal et al. 2008). Some studies have aimed at understanding the Nepal Himalayan landslide mechanisms and processes (e.g., Laban 1979; Selby 1988; Ives and Messerli 1981; Caine and Mool 1982; Wagner 1983; Heuberger et al. 1984; Burbank et al. 1996; Upreti and Dhital 1996; Gerrard1994; Gerrard and Gardner2000; Chalise and Khanal 2001), but there is much less work relating to geological structures, rock weathering, and clay mineralogy in the formation of the landslides in Nepal. A lot of work has been done in this respect in other parts of the world.

Chigira and Sone (1991) studied the effect of chemical weathering mechanisms and their effects on engineering properties of soft sand- stone and conglomerate cemented by zeolite in a mountainous area and found that near the ground surface carbonic acid generated by the dissolution of carbon dioxide from the atmosphere and biological activity in the soil dissolves zeolite, and thereby weakens the rocks. According to Gerber and Scheidegger (1969), fractured rocks crop- ping out in steep slopes experience more intense weathering caused by pre-existing stresses, which favour the degradation of rock strength. Landslides intropical and sub-tropical regions are generally associated with weathered rock profiles which often possess chemical and mineralogical heterogeneities at material and mineral scales. Such heterogeneities reach a climax in the occurrences of oxyhydroxide- and clay-rich zones (Duzgoren-Aydin and Aydin 2006).

According to Petley et al. (2006) landslides in Nepal represent a major constraint on development, causing high levels of economic loss and substantial numbers of fatalities each year. He analysed the database of landslide fatalities in Nepal for the period 1978-2005 and found that there is a high level of variability in the occurrence of landslides from year to year. This is mainly due to unplanned land uses that change the physical and natural systems. Hasegawa et al. (2009) suggest that there was substantial hydrothermal alteration in the Lesser Himalaya during and after the advancement of the Main Central Thrust (MCT) and that clay mineralization in the sliding zones is a major influence on large landslides along the highways of Central Nepal. The MCT is a crustal-scale (1.5 to $3 \mathrm{~km}$ wide) ductile shear zone which emplaces the Oligocene-Miocene metamorphic rocks of the High Himalayan zone south or southwest over the unmetamorphosed or weakly metamorphosed rocks of the Lesser Himalaya (Stephenson et al. 2001).

The Lesser Himalaya consists mainly of phyllites, slates, schists, quartzites, limestones, dolomites, and some amphibolites. These rocks are strongly deformed by the tectonic processes that started during the onset of collision between the Indian Plate and Eurasian Plate about 55 million years ago and which are still in operation. Phyllites are the most susceptible rocks to landsliding, followed by shales, schists, poorly cemented sandstones, gneisses, granites, and quartzites (Gerrard 1994). Rainfall in the Lesser Himalaya of Nepal is quite intense and 
contributes significantly to the weathering of rocks. Thus the rocks here are subject to a high degree of both mechanical and chemical weathering.

This paper focuses on the relationship between rock weathering and formation of landslides in the Nepal Lesser Himalaya. It deals with a major landslide at Dumre Besi on the MuglingNarayanghat Highway in the Lesser Himalaya of central Nepal and describes the causes of failure, together with the mineralogical and geochemical characteristics of rocks and soils comprising the slide zone. The study involved detailed fieldwork and laboratory analysis of rock and soil samples collected from the landslide. In the present study, the degree of rock weathering in the landslide zone is divided into five classes (Table 1) based on the Unified Rock Classification System (modified from Williamson 1984; Geological Society Engineering Working Party 1997; and Hoek and Bray 1997).

\section{Study area}

The Dumre Besi landslide $\left(27^{\circ} 49^{\prime} 14^{\prime \prime} \mathrm{N}, 8^{\circ} 28^{\prime} 42^{\prime \prime}\right.$ E) crosses the Mugling-Narayanghat Highway about $390 \mathrm{~m}$ west of the village of Simaltal, about $12 \mathrm{~km}$ south of Mugling Bazaar. The slide covers an area of about $0.15 \mathrm{~km} 2$ and falls within the topographical map 2784-02D (Jugedi Bajar) published by the Survey Department, Government of Nepal (1995). The land- slide extends from a maximum altitude of 640 to below $220 \mathrm{~m}$ (Fig. 1). A heavy monsoon downpour of 2003 triggered this landslide, together with many others. The Dumre Besi landslide is still actively moving and expanding. It has severely damaged the highway and the traffic is frequently disrupted during the monsoon season.

\section{Climate and hydrology}

The physiographic characteristic and altitude influences the cli- mate in the area. The altitude in the study area ranges between 640 and $220 \mathrm{~m}$, hence sub-tropical to temperate climate prevails here. In winter, temperatures range from 6 to $25^{\circ} \mathrm{C}$ while in summer, they vary from $25^{\circ} \mathrm{C}$ to $40^{\circ} \mathrm{C}$. The monthly maximum temperature and daily rainfall records from the nearby Bharatpur station during 2002-2006 have given a highest maximum temperature of $41.2^{\circ} \mathrm{C}$ in May 2004 and a mean annual rainfall of $2650 \mathrm{~mm}$ (NIPON KOEI Co. 2009). April, May, and June are the hottest months, with average maximum temperatures of $37.8^{\circ} \mathrm{C}, 39.3^{\circ} \mathrm{C}$, and $38.6^{\circ} \mathrm{C}$, respectively. As in other parts of Nepal, the summer monsoon is dominant from June to the end of September. The region receives approximately $80 \%$ of its annual rainfall during the monsoon period (June-September). Rainfall intensities vary throughout the basin, with maximum intensity occurring on south-facing slopes. During the monsoon period, relative humidity too records its maximum value, whereas the temperatures are lower compared with the pre-monsoon period.

\section{Geological and geomorphological setting}

Geological basement rocks along the Mugling-Narayanghat road section are Precambrian rocks of the Nawakot Complex of Central Nepal Lesser Himalaya (Stöcklin and Bhattarai 1978). Dumre Besi landslide consists of rocks belonging to two rock formations, Benighat Slate and Nurpul Formation of the Nawakot Complex (Stöcklin 1980). A geological map of the landslide and its sur rounding area is shown in Fig. 2. Nurpul Formation belongs to the Lower Nawakot 
Group of the Nawakot Complex, while Benighat Slate belongs to the Upper Nawakot Group of the Nawakot Complex. The bedrock in the eastern flank of the landslide is on the Benighat Slates, while its western portion is on the Nourpul Formation, and both of them are separated by a thrust fault. Benighat Slate Formation consists of dark, soft-weathering slates and phyllites; many are argillaceous, and subordinately siliceous or finely quartzitic. The color of the fresh rock is dark bluish grey to nearly black. Nurpul Formation consists of purple quartzite in the lower part, while the middle part of this formation is predominantly phyllitic, but contains a variable amount of quartzitic and calcareous intercalations. The upper part of the Nurpul Formation consists of dolomites and dolomitic quartzites (Stöcklin and Bhattarai 1978). The toe of the landslide lies in the Nurpul Formation while the upper part of the landslide consists of rocks from both the Benighat Slate Formation and Nurpul Formation.

Dumre Besi landslide lies within the Mahabharat Range (Hagen 1969; Upreti 1999). The Dumre River (Fig. 2) drains the study area from south to north and joins just below the road with the Trishuli River flowing from east to west. The Dumre River has two main tributaries that debouch much debris on the road. The average slope gradient of the riverbed ranges from $15^{\circ}$ to $20^{\circ}$. Bushes and small trees cover most of the lower part of the area, while the upper, somewhat flatter portion is cultivated land.

The main body of the landslide can be divided into a main lower part and a small upper part. A narrow gully originates from the upper part of Dumre Besi village and flows through the slide. The upper part of the stream contains a small landslide of about $25 \mathrm{~m}$ width and $100 \mathrm{~m}$ length. Downstream, the stream flows through rocky terrain with waterfalls, and in this area, active bank cutting is widespread. The gully is more than $200 \mathrm{~m}$ in length. The lower main part of the landslide is more than $300 \mathrm{~m}$ long and about $75 \mathrm{~m}$ wide.

\section{Methods}

The landslide was mapped in detail in the field at a scale of 1:50. As well as mapping the landslide, other characteristics recorded in the field were the slope angle and altitude, the lithology of the rock formations in the landslide, the soil and rock types in the landslide zone, and the hydrogeological characteristics of the landslide. Rocks and soils were sampled for laboratory analysis to determine the extent of weathering. Rock samples, both fresh and weathered, representing all of the landslide areas were collected. In addition, the major geological structures present within the landslide area were analysed.

Our investigations were conducted to understand the role of rock weathering and clay minerals in the formation of the land- slide. The rock and soil samples from the landslide zone were analysed using an optical microscope, X-ray powder diffraction of whole rock samples, X-ray diffraction (XRD) of clay minerals separated by a density method, X-ray fluorescence (XRF), and various other analytical techniques. These techniques were used to trace mineral alterations and to evaluate the alterations within a broader framework of the bulk changes occurring in the whole rock during the weathering process. 


\section{Detailed description of the landslide}

Dumre Besi landslide is one of the most active landslides along the Mugling-Narayanghat road section (Fig. 3); it was first recognized after the 2003 rainfall, when a small part of it activated below the Dumre Besi near Simaltal and damaged the road. In the same year, many other landslides were initiated along this road section, and the road was closed for several days. Since then, the road has been closed for some hours to some days in every monsoon due to this and other instabilities along the road.

The Dumre Besi landslide has two large scarps developed in each of the tributaries of the Dumre River and they coalesce downstream to form a single complex failure (Fig. 4) involving several types of movement (Cruden and Varnes 1996). The top of the slide reaches the Dumre village, situated above the road, while its toe lies at the cut bank of the Trishuli River, below the road. The crown of the landslide is on the Benighat Slates and Nourpul Formation, while the toe is on the Nourpul Formation (Fig. 3). The cross-section across the landslide (Fig. 5) shows its main components. Its upper part is covered by soil with some sparse vegetation, whereas the central zone, from where the thrust passes, contains thick landslide debris with sporadic exposures of severely weathered rock, and the lower portion includes some rock out- crops exhibiting slight weathering. From the cross-section, it can be seen that the thrust has a prominent role in the formation of the weathered material.

The lower part of the landslide consists of light to dark grey phyllite, and siltstone with abundant quartz veins and crenulation cleavage. The dark grey phyllites are interbedded with fine-grained sandstones that commonly contain tension cracks and quartz veins. The phyllite and slate are fresh to slightly weathered, while the sandstone shows no weathering (Fig. 6). The attitude of the foliation plane is $263^{\circ} / 68^{\circ} \mathrm{NW}$ and the attitudes of joint are: $\mathrm{J} 1=218^{\circ} / 65^{\circ} \mathrm{SE}, \mathrm{J} 2=145^{\circ} / 38^{\circ} \mathrm{S}$, and $\mathrm{J} 3=005^{\circ} / 69^{\circ} \mathrm{NW}$. Several gabion walls have been constructed to control debris. The foundation of one gabion wall is about $20 \mathrm{~m}$ upstream of Dumre River; the foundation is on light grey to dark grey, thinly laminated phyllite and sandstone, but the rock mass is rather unstable. Another gabion wall is founded on light grey, weathered phyllite and is about $35 \mathrm{~m}$ upstream from the other wall.

The rock types along the central part of the landslide are mainly light grey to dark grey phyllite alternating with a few thin metasandstone bands. About $130 \mathrm{~m}$ uphill from the road, on the left bank of the stream, highly sheared light- to dark-grey phyllite is observed. Nearby are two areas of springs and a seepage zone.

A large landslide (35 m long, $20 \mathrm{~m}$ wide, and 1-3 m deep) occurs on the left bank of the gully. The material is colluvial gravel, with clasts ranging in size from 0.2 to $2 \mathrm{~m}$. Scattered boulders in the gully are composed of highly weathered fine-grained, greenish- grey sandstone and folded black carbonaceous shale. The sides of the landslide are covered by a residual soil with a thickness of $2-5 \mathrm{~m}$. On the right bank of the gully, highly fractured, moderately weathered, white phyllite is observed. The channel is covered by large boulders, with diameters of up to $7 \mathrm{~m}$ (Fig. 7); most are of coarse-gained, grey sandstone. The matrix between the large boulders is 
composed of highly weathered greenish-grey siltstone and black carbonaceous shale. The area is wet and there are many spring and seeps.

On the right side of the gulley is a colluvial slide about $7 \mathrm{~m}$ deep. The landslide mass is made up of gravel, with grains ranging in size from 0.2 to $2 \mathrm{~m}$ and composed of greenish-grey siltstone and phyllite. The rocks here are highly crushed and weathered (Fig. 8). The other tributary of the Dumre River, about $40 \mathrm{~m}$ up the hillside from the road, consists of alterations of light grey metasandstone and phyllites. The gully is narrow (ca. $3 \mathrm{~m}$ ) and its depth is about $7 \mathrm{~m}$. The upstream part contains highly folded and fractured light grey slate. Most of the rocks are highly weathered (Fig. 6).This tributary contains fewer landslides than the other tributary. As the rocks are highly deformed here, the foliation is variable and ranges between $165^{\circ} / 39^{\circ} \mathrm{NE}$ and $140^{\circ} / 47^{\circ} \mathrm{NE}$ for Nourpul Formation and $250^{\circ} / 78^{\circ} \mathrm{NW}$ and $251^{\circ} / 74^{\circ} \mathrm{NW}$ for Benighat Slate Formation. There are two joint sets (J1 and J2) in the rocks of the Nourpul Formation; the attitude of joint set J1 is $190^{\circ} / 45^{\circ} \mathrm{SE}$, and for $\mathrm{J} 2$ it is $118^{\circ} / 56^{\circ} \mathrm{SW}$.

The landslide consists of two rock formations separated by a thrust fault; the rocks of the Benighat Slate Formation that crop out in the upper part of landslide consist of slightly weathered, light grey laminated dolomite, interbedded with light grey slate and, highly jointed and fractured, light grey phyllite and sandstone. The attitude of bedding planes is about $230^{\circ} / 74^{\circ}$ NW. The rocks belonging to Nourpul Formation, forming the upper part of the landslide, consist of light grey to white, laminated, shiny phyllite and metasandstone. The rock is slightly weathered (Fig. 5).

The thrust fault that passes through the central part of the landslide has created a thick crushed and sheared zone more than $15 \mathrm{~m}$ thick (Fig. 8).Highly folded and sheared black carbonaceous slate can be seen just near the thrust (Fig. 8), and rocks are highly deformed along the side of the thrust. This is the major source of debris in the stream. The rock around the thrust is mainly white deformed phyllite and black carbonaceous slate. These rocks are almost crushed to powder. The water flowing from this area is turbid with clay.

The main lithology in the landslide zone is thinly laminated light grey siltstone with cross-cutting quartz veins, grey sandstone (quartzite), bluish grey to white phyllite, black carbonaceous shale, and dolomite. The channel draining the landslide area is mostly covered by large boulders up to $7 \mathrm{~m}$ in diameter (Fig. 7). The boulders are of grey coarse-grained sandstone in a matrix of weathered, greenish grey siltstone and black carbonaceous shale/ slate, highly crushed and powdered fine sandstone, weathered white-colored phyllite, and some bluish grey dolomite.

The heavy monsoon rainfall of 2003 triggered the landslide, and the volume of debris deposited along the road during that period was about $29,000 \mathrm{~m} 3$. The thrust has created a very shattered zone about $15 \mathrm{~m}$ thick (Fig. 8). Runoff easily infiltrates this zone, facilitating the weathering of rocks. This creates much loose material on the slope, which can easily be carried by the flowing water. The upper part of the crown and the sides of the landslide are covered by a thick deposit of residual soil and crumbled rock fragments. During rainy periods, materials from the landslide, as well as from above the crown and sides of the landslide, flow into the stream. The stream transports this debris downhill, depositing it on the road. Figure 9 shows the major sources of 
debris and the mechanism of their flow. The main materials in the debris are rock fragments from weathered phyllite and black slate, and fine- grained muddy materials with greenish fresh phyllite, dolomites, and some argillaceous phyllite. The debris material ranges in size from boulder to clay. However, cobble- to pebble-size material dominates in the debris.

\section{Laboratory studies}

Laboratory analyses were used to determine the mineralogy of the materials from the landslide zone, and the major and trace elements in the rocks from the landslide zone.

\section{Thin section and X-ray diffraction analysis}

The main mineralogical constituents of the rocks along the land- slide zone were determined from thin sections made from fresh and weathered rock samples (Fig. 10) and confirmed using XRD. XRD studies were made of randomly oriented specimens to examine mineral species in bulk samples, and on oriented specimens to facilitate clay-mineral identification. For the oriented specimens, the bulk samples were powdered and then centrifuged after suspension in water to obtain clay fractions $<2 \mu \mathrm{m}$ in size. The bulk and oriented specimens were analysed with graphite-monochromatized $\mathrm{CuK \alpha} 40 \mathrm{kV}$ and $40 \mathrm{~mA}$. The diffractometer was calibrated using silicon as an external standard.

Table 2 shows the distribution of minerals in different rocks from the landslide zone. From the analysis of the thin sections and XRD pattern of the rock samples, the fresh rocks consist of minerals such as quartz, feldspar, muscovite, and opaque minerals (Table 2), while the weathered rocks are rich in clay minerals and some quartz, muscovite, chlorite, calcite, and opaque minerals (Table 3). Few very well-developed crystals of muscovite can be seen in thin sections. The XRD analysis of the weathered rocks revealed that they are clay-rich. The main clay minerals were much smectite, chlorite, with some vermiculite. This was confirmed by oriented aggregate analysis and ethylene glycol treatment analysis (Fig. 11). Table 3 shows the distribution of clay minerals in both fresh and weathered rocks from some of the collected rock samples.

\section{X-ray fluorescence analysis}

Five rock samples of phyllite and slate from the landslide zone were analysed by the XRF method. The analyses followed the method of Miyake et al. (1996), using glass beads prepared with alkali flux comprising lithium tetraborate (Li2B4O7) and a flux-to- sample ratio of 2:1. The glass beads thus prepared were analysed by XRF analysis using a PHILIPS PW400 spectrometer with an Rh anode tube at the Faculty of Science, Shinshu University, Japan. Tables 4 and 5 show the wt $\%$ of major and trace elements contained within both the fresh and weathered rocks from the landslide zone.

From the XRF analysis of rock samples, it was determined that the $\mathrm{SiO} 2$ and $\mathrm{A} 12 \mathrm{O} 3$ contents in phyllites range from 68.4 to 65.81 and 15.62 to 16.03 of their total wt $\%$ respectively. The concentration of these components is higher in the weathered rocks than in the fresh rocks. This is due to the depletion of mobile components by weathering. Since the $\mathrm{SiO} 2$ content in 
unweathered slates is higher than in any other fresh rock, they are less affected by chemical alteration, but they suffer from intense physical weathering. According to Taylor and Eggleton (2001), quartz grains are residual in weathering profiles on quartz-bearing rocks and quartz increases in abundance relative to other primary minerals. Also McQueen and Scott (2008) have shown that quartz and secondary silica persist over a very wide range of weathering conditions. In addition, Velde and Meunier (2008) suggest that quartz remains as a residual mineral in weathering profiles even after all silicates are dissolved. Finally, Schmitt (1999) noted that the relative abundance of quartz increases in the initial stage of weathering of granite in a weathering simulation. The $\mathrm{CaO}$ and $\mathrm{K} 2 \mathrm{O}$ contents in both phyllite and slate are lower in the weathered state than in the fresh. This is due to the fact that these components are easily dissolved in water and subsequently carried away. Figure 12 shows the plot of $\mathrm{MgO}$ and $\mathrm{CaO}$ against $\mathrm{Al} 2 \mathrm{O} 3$ for both the slate and phyllite. In order to quantify the degree of weathering, the Chemical Index of Alteration (CIA; Nesbitt and Young 1989) was calculated using the molecular proportions as shown in the equation below:

$$
C l A=\left(\frac{A l 203}{A l 203+C a O+N a 2 O+K 20}\right) \times 100 \%
$$

The CIAs of both fresh and weathered rocks are shown in Fig.13. The CIA value of fresh phyllite is 57.08 while that of highly weathered phyllite is 61.73 . In the case of slate, it is 70.81 for slightly weathered and 75.31 for weathered slate. This shows that the CIA value increases as the rock becomes more weathered, which is in accordance with the available literature (Price and Velbel 2003). From the geochemical analysis, it is seen that the elemental concentration of trace elements such as $\mathrm{Ni}, \mathrm{Zn}, \mathrm{Ga}$, and $\mathrm{Nb}$ are below background levels, while the others are in the normal range. This suggests that these rocks are not significantly affected by hydrothermal alteration.

\section{Discussion}

The Dumre Besi landslide is a complex mass movement, consisting of both rockslides and debris flows. Though the main trigger is rainfall, other additional factors such as geological structure, rock weathering, and clay minerals formed during rock weathering have also affected the failure. The groundwater level too is very high in the landslide zone and has a significant effect on landslide development.

The outcropping rock in the landslide zone varies from un- weathered to completely weathered types, as evident from field and laboratory analyses. The studies indicate that the weathering in the Dumre Besi landslide is complex, as the fresh and weathered rocks are intermixed and it is difficult to differentiate between weathering grade 4 and 5 in certain parts (Fig. 6).Most of the slate in the landslide zone seems to be chemically less altered. As the landslide is very active, the weathered slate could have easily been removed by erosion and running water. Rocks are exposed only in some areas (e.g., near the thrust zone) and a large tract of the landslide zone is covered by colluvium and fines. The debris in the channel is represented by highly weathered, fine-grained, greenish grey sandstone, and black carbonaceous shale, derived primarily from the Benighat Slates. 
Most of the clay minerals in the landslide zone were derived from chemical weathering of rocks. Weathering is facilitated by deformation and crushing associated with a thrust fault which passes through the middle part of the landslide. Water easily enters the crush zone, and facilitates rock weathering. Thin section studies and XRD analysis of rocks show that the area around the thrust is highly weathered and rich in clay minerals (Table 3).Chlorite, smectite, zeolite, and vermiculite were observed in the landslide zone (Table 3).Smectite and vermiculite were the weathering product, while zeolite may have been formed by hydrothermal alteration during regional metamorphism. But, its role in the landslide is not noticed as it is mostly found in less weathered rocks. However, chlorite is not the weathering product here, as we know that it is a common metamorphic mineral, usually indicative of low-grade metamorphism. The clay minerals have an adverse effect on slope stability. Firstly, their development decreases the strength of rocks; secondly some clay minerals such as smectite swell when wet. The present study suggests that the weathered rocks are rich in smectite. According to Gerber and Scheidegger (1969) fractured rocks cropping out in steep slopes are subjected to more intense weathering caused by pre-existing stresses, which favour the degradation of rock strength. The thrust has created a wide crush zone, where the rainwater easily infiltrates the ground and facilitates both physical and chemical weathering of rocks. Physical weathering breaks the rock into smaller fragments on which chemical weathering can proceed very easily. Thus, rock weathering has a profound effect on the formation of the Dumre Besi landslide and similar other failures in its vicinity.

The rocks in this landslide zone consist of quartz, muscovite, feldspar, calcite, and many clay minerals. The XRF analysis suggests that the rocks are highly affected by weathering and most of the clay minerals are formed from weathering of rocks. As the rocks are highly weathered around the thrust zone, where most of the landslides are concentrated, it follows that the thrust faulting, rock weathering, landslide formation, and debris flows are closely interlinked. However, in thin section, a few very well-developed crystals of muscovite can be seen along veins. This muscovite may have been formed from hydrothermal alteration; but there is no relation between this muscovite and the clay minerals developed in rocks since almost all clay minerals were derived from weathering of rocks.

There are very few studies relating landslides to rock structure and rock weathering in Nepal. Some research from Nepal Himalaya by Hasegawa et al. (2009) suggested that the clay minerals were developed by hydrothermal alteration. However, most of the clay minerals in the Dumre Besi landslide were formed by rock weathering and not by hydrothermal alteration. Hydrothermal alteration may be evident in some parts of the Himalayas, but it is not necessary that all the rocks of the Himalaya have been affected by hydrothermal fluids. More rigorous studies need to be done in other parts of the Himalaya to determine the processes of clay mineral formation in other landslide zones, and also the role of geological structure and rock weathering within those areas.

A study of the distribution of clay minerals along a weathered pyroclastic profile in Hong Kong (Duzgoren-Aydin et al. 2002) suggests that clay-rich zones in weathered profiles developed over igneous rocks play a significant role in the occurrence of relatively large-scale landslides in 
Hong Kong and elsewhere. Watanabe et al. (2005) studied 19 watersheds in Shirouma-Oike Volcano in the western part of the Hiem River Basin, Japan, and found that most of the largescale landslides were located where the chemical weathering is highest. A study of rock weathering and shallow landslide generation in southern Kyushu, Japan (Chigira and Yokoyama 2005) found that clay minerals formed by weathering of rocks may clog in interstices to form clay-rich bands, which act as impermeable barriers. Thus, the water cannot flow through, and so it increases the weight of the weathered material, which leads to failure. The failure material is derived from the long-term weathering of rocks. Some studies were done in Calabria, southern Italy, relating to rock weathering and landslide formation (Calcaterra and Parise 2005, 2010). According to them almost all types of landslide were observed in the Serre Massif of Calabria (Italy), which has been affected by tectonic and adverse climatic condition since Tertiary time, which resulted in deep weathering of crystalline rocks. They were able to map landslides based on the degree of weathering of rocks. Parise et al. (2004) reported that intense and/or continuous weathering processes may result in thick sequences of complex and heterogeneous materials characterized by physical and geotechnical properties which have been strongly altered by the action of weathering. As a consequence, they may be prone to slope failures, erosion and landslides. Weathering affects joint or fault gouge material in the Swiss Alps, leading to the formation of smectite, which changes the mechanical properties of fault gouge and degrades slope performance (Jaboyedoff et al. 2004).

\section{Conclusion}

Rainfall was the primary trigger of the Dumre Besi landslide, and secondary triggers, operating over a long time, were geological structure, rock weathering and the formation of clay minerals. Steep slope angles, rugged topography, and groundwater were also responsible for the formation of this landslide. A thrust passes through the center of the landslide and has created a thick zone of fault gouge and breccia. The rocks are highly and complexly weathered around this thrust. The weathering in the landslide can be divided into five grades, and all grades of weathering (i.e., from fresh rock to residual clay) are observed here. The weathering is complex. Thin section, XRD and XRF analyses of the collected rock samples show that chlorite, smectite, and vermiculite were formed during weathering. These clay minerals reduce the rock strength, and in addition, smectite swells when wet. As a result, weathering and thrusting have created a thick zone of clay-rich loose material, which moves as debris flows in every monsoon season.

\section{Acknowledgements}

The authors express their hearty thanks to the Department of Geol- ogy, Shinshu University, for providing the laboratory facilities for the analysis of collected rock and soil samples. Also, the authors would like to thank Mr. Bimal Raj Regmi for his great help during the field mapping of the landslide and in the collection of rock and soil samples, and Miss Yuka Shiga for her help during the preparation of samples for XRF analysis and in other lab work. The authors would also like to thank Prof. Makina, Prof. Miyake, and Mr. Tsugane for their help during the XRD and XRF analysis of rock samples. 


\section{References}

Brundsen D, Doornkamp JC, Fookes PG, Jones DKC, Kelly JMH (1975) Large-scale geotechnical mapping and highway engineering design. Q J Eng Geol 8:227-253

Burbank DW, Leland J, Brozovic EN, Reid MR, Duncan C (1996) Bedrock incision, rock uplift and threshold hillslopes in the northwestern Himalayas. Nature 379(6565):505-510

Caine N, Mool PK (1982) Landslides in the Kolpu Khola drainage, Middle Mountains, Nepal. Mt Res Dev 2:157-173

Calcaterra D, Parise M (2005) Landslide types and their relationships with weathering in a Calabrian basin, southern Italy. Bull Eng Geol Environ 64:193-207

Calcaterra D, Parise M (2010) Weathering as a predisposing factor to slope movements: an introduction. Geological Society, London, Eng Geol Special Publications 23:1-4

Chalise SR, Khanal NR (2001) Rainfall and related natural disasters in Nepal. In: Tianchi L, Chalise SR, Upreti BN (eds) Landslide hazards, mitigation to the Hindukush-Himalayas. ICIMOD, Kathmandu, pp 63-70

Chigira M, Sone K (1991) Chemical weathering mechanisms and their effects on engineering properties of soft sandstone and conglomerate cemented by zeolite in a mountainous are. Eng Geol 30:195-219

Chigira M, Yokoyama O (2005) Weathering profile of non-welded ignimbrite and the water infiltration behavior within it in relation to the generation of shallow landslides. Eng Geol 78:187-207 
Cruden DM, Varnes DJ (1996) Landslide types and processes. In: Turner AK, Schuster RL (eds) Landslide investigation and mitigation, Special Report 247. Transportation Research Board, National Research Council, National Academy Press, Washington, DC, pp 36-75

Dahal RK, Hasegawa S, Nonomura A, Yamanaka M, Dhakal S, Paudyal P (2008) Predictive modelling of rainfall-induced landslide hazard in the Lesser Himalaya of Nepal based on weights-of-evidence. Geomorphology 102:496-510

Dangol V (2000) Slope instability study and hazard mapping of Syangja district, Western Nepal. Unpublished Report, ICIMOD, Katmandu, Nepal

Dangol V, Upreti BN, Dhital MR, Wagner A, Bhattarai TN, Bhandari AN, Pant SR, Sharma MP (1993) Engineering geological study of a proposed road corridor in Eastern Nepal. Bull Dept Geol Tribhuvan University, 3(1), Special Issue, 91-107

Deoja B, Dhital MR, Thapa B, Wagner A (1991) Mountain risk engineering handbook. ICIMOD, Kathmandu, 857pp

Dhital MR, Upreti BN, Dangol V, Bhandari AN, Bhattarai TN (1991) Geological engineering methods applied in mountain road survey: an example from Baitadi-Darchula Road Project (Nepal). J Nepal Geol Soc 7:49-67

Duzgoren-Aydin NS, Aydin A (2006) Chemical and mineralogical heterogeneities of weathered igneous profiles: implications for landslide investigations. Nat Hazards Earth Syst Sci $6: 315-322$

Duzgoren-Aydin NS, Aydin A, Malpas J (2002) Distribution of clay minerals along a weathered pyroclastic profile, Hong Kong. Catena 50:17-41

Geological Society Engineering Working Party (1997) The Description of Rock Masses for Engineering Purposes. Q J Eng Geol 10(4):355-388

Gerber E, Scheidegger AE (1969) Stress-induced weathering of rock masses. Eclog Geol Helv $62: 401-416$

Gerrard J (1994) The landslide hazard in the Himalayas: geological control and human action. Geomorphology 10:221-230

Gerrard J, Gardner RAM (2000) Relationships between rainfall and landsliding in the Middle hills Nepal. Norsk Geogr Tidsskr 54:74-81

Hagen T (1969) Report on the geological survey of Nepal preliminary reconnaissance. Zurich, Mémoires de la Soc. Helvétique des Sci. Naturelles, 185pp 
Hasegawa S, Dahal RK, Yamanaka M, Bhandari NP, Yatabe R, Inagaki H (2009) Causes of large landslides in the Lesser Himalaya of central Nepal. Environ Geol 57:1423-1434

Heuberger H, Masch L, Preuss E, Schrocker A (1984) Quaternary landslides and rock fusion in central Nepal and in the Tyrolean Alps, vol 4. Mountain Research and Development, University of California Press, Berkeley, pp 345-362

Hoek E, Bray JW (1997) Rock slope engineering. Institute of Mining and Metallurgy, London, $402 \mathrm{pp}$

Ives JD, Messerli B (1981) Mountain hazards mapping in Nepal; introduction to an applied mountain research project, vol 1. Mountain Research and Development, University of California Press, Berkeley, pp 223-230

Jaboyedoff M, Baillifard F, Bardou E, Girod F (2004) The effect of weathering on Alpine rock instability. Q J Eng Geol Hydrol 37:95-103

Kienholz H, Hafner H, Schneider G, Tamrakar R (1983) Mountain hazards mapping in Nepal's Middle Mountains, maps of land use and geomorphic damage (Kathmandu- Kakani area). Mt Res Dev 3(3):195-220

Kienholz H, Schneider G, Bichsel M, Grunder M, Mool P (1984) Mapping of mountain hazards and slope stability. Mt Res Dev 4(3):247-266

Kojan E (1978) Report on landslide problems, western hill road project, Godavari to Dandeldhura, Nepal. Unpublished Report, USAID

Laban P (1979) Landslide occurrence in Nepal. HMG/FAO and UNDP, Ministry of Forest, Department of Soil Conservation, Integrated Watershed Management, Kathmandu, 27

McQueen KG, Scott KM (2008) Rock weathering and structure of the Regolith. In: Scott KM, Pain CF (eds) Regolith science. CSIRO Publishing, Melbourne, pp 103-124

Miyake Y, Tsugane T, Kanai T, Ikemoto M (1996) X-ray fluorescence analysis of major elements in silicate rocks-preparation of glass bead pellets of a high ratio of sample to flux and the accuracy of the rapid analysis. J Fac Sci Shinshu Univ 31:105-117

Nesbitt HW, Young GM (1989) Formation of diagenesis of weathering profiles. J Geol 97:129147

NIPON KOEI Co. Ltd (2009) The study on disaster risk management for NarayangharhMugling Highway. Unpublished Report 
Parise M, Calcaterra D, Larsen MC (2004) Introduction to Weathering and Slope Movement papers. Q J Eng Geol Hydrogeol 37:76

Petley DN, Hearn GJ, Hart A, Nj R, Dunning SA, Oven K, Mitchell WA (2006) Trends in landslide occurrence in Nepal. Nat Hazard 43:23-44

Price JR, Velbel MA (2003) Chemical weathering indices applied to weathering profiles developed on heterogeneous felsic metamorphic parent rocks. Chem Geol 202:397- 416

Schmitt JM (1999) Weathering, rainwater and atmosphere chemistry: example and modelling of granite weathering in present conditions in a CO2-rich, and in an anoxic palaeoatmosphere, palaeoweathering, palaeosurfaces and Related Continental Deposits. In: Thiry M, Simon-Coinçon R (eds) Spec Publs Int Ass Sediment 27:21-41

Selby MJ (1988) Landforms and denudation of the High Himalaya of Nepal: results of continental collision. Z Geomorphol Neue Folge 69:133-152, Supplementeband

Stephenson J, Searl MP, Waters DJ (2001) Structure of the Main Central Thrust zone and extrusion of the High Himalayan crustal wedge, Kishtwar-Zanskar Himalaya. J Geol Soc London 158:637-652

Stöcklin J (1980) Geology of Nepal and its regional frame. J Geol Soc London 137:1-34

Stöcklin J, Bhattarai KD (1978) Geology of the Kathmandu area and central Mahabharat range, Nepal Himalaya. Report of Department of Mines and Geology/UNDP (unpub- lished), $86 \mathrm{p}$

Taylor G, Eggleton RA (2001) Regolith geology and geomorphology. Wiley

Upreti BN (1999) An overview of the stratigraphy and tectonics of the Nepal Himalaya. J Asian Earth Sci 17:57-606

Upreti BN, Dhital MR (1996) Landslide studies and management in Nepal. ICIMOD, Nepal, $87 \mathrm{pp}$

Velde B, Meunier A (2008) The origin of clay minerals in soils and weathered rocks. Springer, New York, 406p

Wagner A (1981) Rock structure and slope stability study of Waling area, central west Nepal. J Nepal Geol Soc 1(2):37-43

Wagner A (1983) The principal geological factors leading to landslides in the foothills of Nepal: a statistical study of 100 landslides-steps for mapping the risk of landslides. 
HELVETAS-Swiss Technical Cooperation and ITECO-Company for International Cooperation and Development, unpublished, pp 58

Watanabe N, Yonekura N, Sagara W, Cheibany OE, Mauri H, Furuya G (2005) Chemical weathering and large scale landslides in the Hime River Basin, Central Japan. Landslides Risk Analysis and Sustainable Disaster Management 165-171

Williamson DA (1984) Unified rock classification system. Bull Assoc Eng Geol 21(3):345- 354 
Table 1 Table showing the weathering degree of rocks (modified from Williamson 1984; Geological Society Engineering Working party 1997; and Hoek and Bray 1997)

\begin{tabular}{|l|l|l|}
\hline State & Definition & Description \\
\hline 1 & Degree of Weathering & \\
\hline 2 & None & No visible sign of weathering \\
\hline 3 & Mlight & $\begin{array}{l}\text { Discoloration on major discontinuity surfaces; rock } \\
\text { material may be discolored and somewhat weaker than }\end{array}$ \\
\hline 4 & Severe & $\begin{array}{l}\text { Less than half of the rock is present either as a continuous } \\
\text { framework or as corestones }\end{array}$ \\
\hline 5 & Complete & $\begin{array}{l}\text { Most of rock material is decomposed; disintegrated to a } \\
\text { soil, or both; original mass structure is largely intact }\end{array}$ \\
\hline
\end{tabular}


Table 2 Thin section analysis of rocks

\begin{tabular}{|c|c|c|c|c|c|c|c|c|}
\hline \multirow{3}{*}{ Loc. } & \multirow{3}{*}{ Occurrence } & & & & \multicolumn{4}{|c|}{ Minerals } \\
\hline & & \multicolumn{5}{|c|}{ Original minerals minerals } & \multicolumn{2}{|r|}{ Derived } \\
\hline & & Quartz & Muscovite & Albite & Calcite & Pyrite & $\begin{array}{c}\text { Clay } \\
\text { minerals }\end{array}$ & Opaque minerals (Iron oxides) \\
\hline Sp1 & Light gray fresh phyllite & ++ & ++++ & ++ & & + & $++(\mathrm{Sm})$ & + \\
\hline Sp2 & Greenish gray fresh phyllit & ++++ & ++ & & & & $+(\mathrm{Sm})$ & \\
\hline Sp3 & Slightly weathered light gray phyllite & & + & & ++++ & & + & \\
\hline Sp4 & Fine grained, slightly weathered metasandstone & ++++ & ++ & & & & ++ & + \\
\hline Sp5 & Weathered greenish gray phyllite & +++ & ++ & & ++ & & $+++(\mathrm{Sm})$ & \\
\hline Sp6 & Weathered fine grained metasandstone & +++ & ++ (folded) & & & & ++ & ++ (May be some zircon) \\
\hline Sp7 & Powdered ash gray colored silty clay & ++++ & + & & & & +++ & ++ \\
\hline Sp8 & Phyllite from sheared zone & ++ & ++ & & +++ & & +++ & \\
\hline Sp9 & Slightly weathered light gray phyllite & ++++ & & & & & ++ & + \\
\hline Sp10 & Slightly weathered black carbonaceous slate & & & & & & & \\
\hline Sp11 & Moderately weathed black slate & & & & ++ & & ++++ & \\
\hline Sp12 & Weathered black slate & & + & & & & ++++ & \\
\hline Sp13 & Weathered black slate & & & & ++++ & & ++++ & \\
\hline Sp14 & Crushed black sandstone & ++ & +++ & & & & ++ & + \\
\hline Sp15 & Weathered black slate & ++ & & & + & & +++ & +(red opaque mineral) \\
\hline Sp16 & Fresh black slate & & & & +++ & & ++ & + \\
\hline
\end{tabular}


Table 3 Type of clay minerals observed by gravity settling method in XRD in some selected rock samples

\begin{tabular}{|l|l|l|l|l|}
\hline Loc. & Occurrence & Chlorite & Smectite group & Zeolite \\
\hline Sp1 & Light gray fresh phyllite & ++ & & \\
\hline Sp5 & Severely weathered greenish gray phyllite & + & ++ & \\
\hline Sp6 & Moderately weathered fine grained metasandstone & ++ & & \\
\hline Sp7 & Powdered ash-gray colored silty clay & +++ & & ++ \\
\hline Sp8 & Phyllite from sheared zone & ++ & +++ & \\
\hline Sp9 & Severely weathered light gray phyllite & ++ & +++ & \\
\hline Sp11 & Moderately weathered black slate & & & ++ \\
\hline Sp12 & Weathered black slate & ++ & & \\
\hline Sp15 & Weathered black slate & ++ & & \\
\hline Sp16 & Fresh black slate & ++ & & \\
\hline
\end{tabular}


Table 4 Proportions (\%) of major elements observed in selected samples from Dumre Besi landslide

\begin{tabular}{|c|c|c|c|c|c|}
\hline Elements & SP1 (Fresh phyllite) & SP7 (Powdered ash-gray phyllite & SP9 (Severely weathered phyllite) & SP14 (Crushed black slate) & SP16 (Slightly weathered slate) \\
\hline $\mathrm{SiO} 2$ & 65.81 & 67.51 & 68.4 & 69.56 & 75.82 \\
\hline $\mathrm{TiO} 2$ & 0.59 & 0.48 & 0.56 & 0.65 & 0.56 \\
\hline $\mathrm{Al2O}$ & 15.62 & 16.01 & 16.03 & 15.06 & 13.25 \\
\hline $\mathrm{Fe} 2 \mathrm{O} 3$ & 4.59 & 3.84 & 4.98 & 6.03 & 2.8 \\
\hline $\mathrm{MnO}$ & 0.05 & 0.06 & 0.03 & 0.01 & 0 \\
\hline $\mathrm{MgO}$ & 3.77 & 2.76 & 1.9 & 3.94 & 2.45 \\
\hline $\mathrm{CaO}$ & 2.25 & 2.47 & 0.9 & 0.03 & 0.14 \\
\hline $\mathrm{Na} 2 \mathrm{O}$ & 0.1 & 1.19 & 1.34 & 0.21 & 0.13 \\
\hline $\mathrm{K} 2 \mathrm{O}$ & 7.05 & 5.57 & 5.74 & 4.32 & 4.71 \\
\hline $\mathrm{P} 2 \mathrm{O} 5$ & 0.17 & 0.11 & 0.12 & 0.18 & 0.13 \\
\hline total & 100 & 100 & 100 & 100 & 100 \\
\hline
\end{tabular}


Table 5 Trace elements observed in selected samples from Dumre Besi landslide (unit ppm)

\begin{tabular}{|l|l|l|l|l|l|}
\hline Elements & $\mathrm{SP} 1$ & $\mathrm{SP7}$ & $\mathrm{SP9}$ & $\mathrm{SP} 14$ & $\mathrm{SP} 16$ \\
\hline $\mathrm{V}$ & 87 & 68 & 102 & 111 & 89 \\
\hline $\mathrm{Cr}$ & 78 & 36 & 60 & 56 & 53 \\
\hline $\mathrm{Ni}$ & 21 & 20 & 20 & 13 & 17 \\
\hline $\mathrm{Zn}$ & 10 & 4 & 4 & 10 & 6 \\
\hline $\mathrm{Ga}$ & 17 & 19 & 20 & 17 & 12 \\
\hline $\mathrm{Rb}$ & 247 & 238 & 243 & 117 & 146 \\
\hline $\mathrm{Sr}$ & 33 & 21 & 15 & 13 & 8 \\
\hline $\mathrm{Zr}$ & 203 & 221 & 158 & 205 & 176 \\
\hline $\mathrm{Nb}$ & 12 & 12 & 14 & 13 & 12 \\
\hline $\mathrm{Ba}$ & 211 & 169 & 149 & 441 & 367 \\
\hline $\mathrm{La}$ & 77 & 61 & 54 & 46 & 66 \\
\hline $\mathrm{Ce}$ & 127 & 122 & 108 & 116 & 137 \\
\hline $\mathrm{Nd}$ & 47 & 44 & 40 & 40 & 48 \\
\hline
\end{tabular}




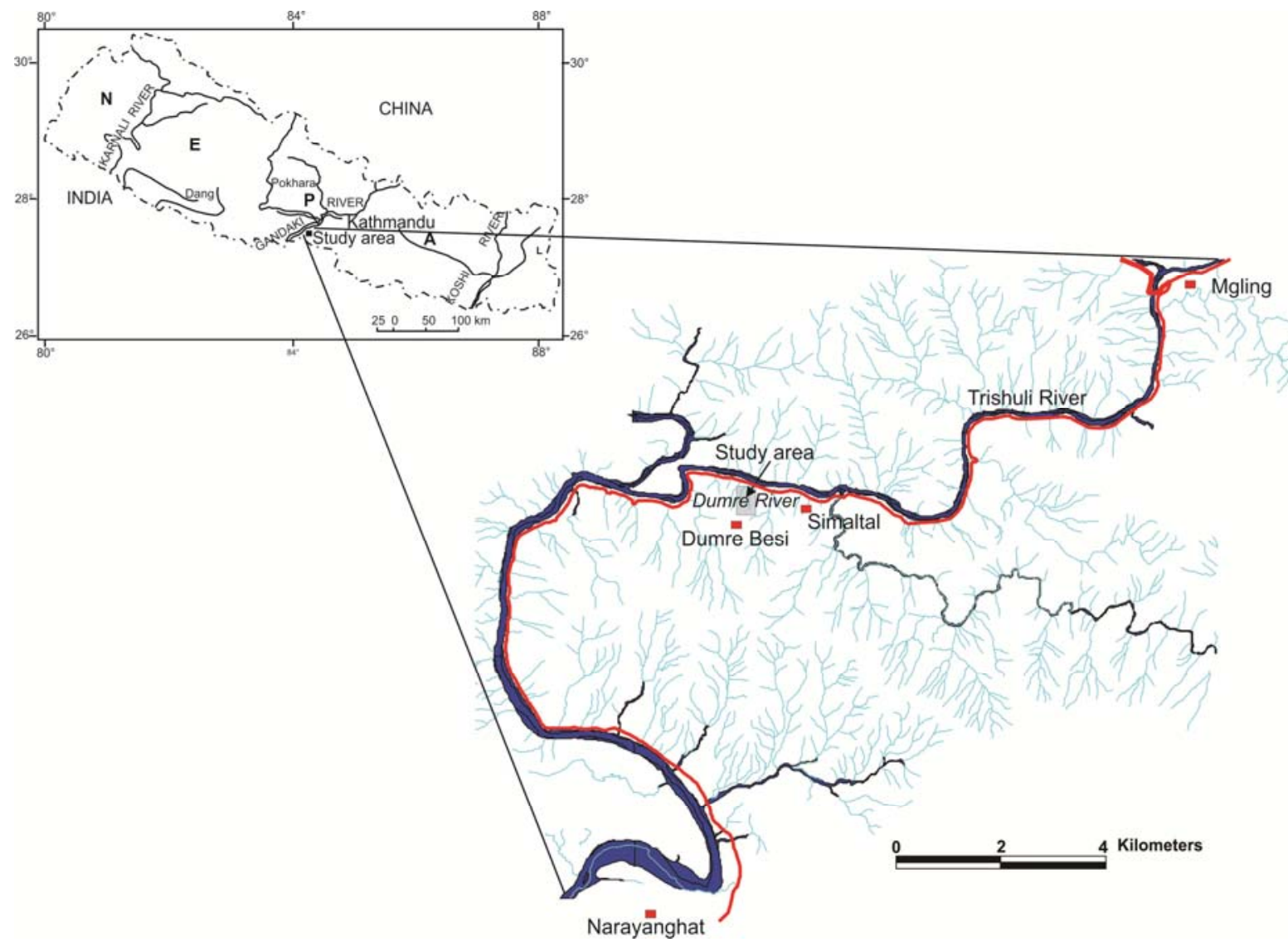

Fig. 1 Map showing the study area 


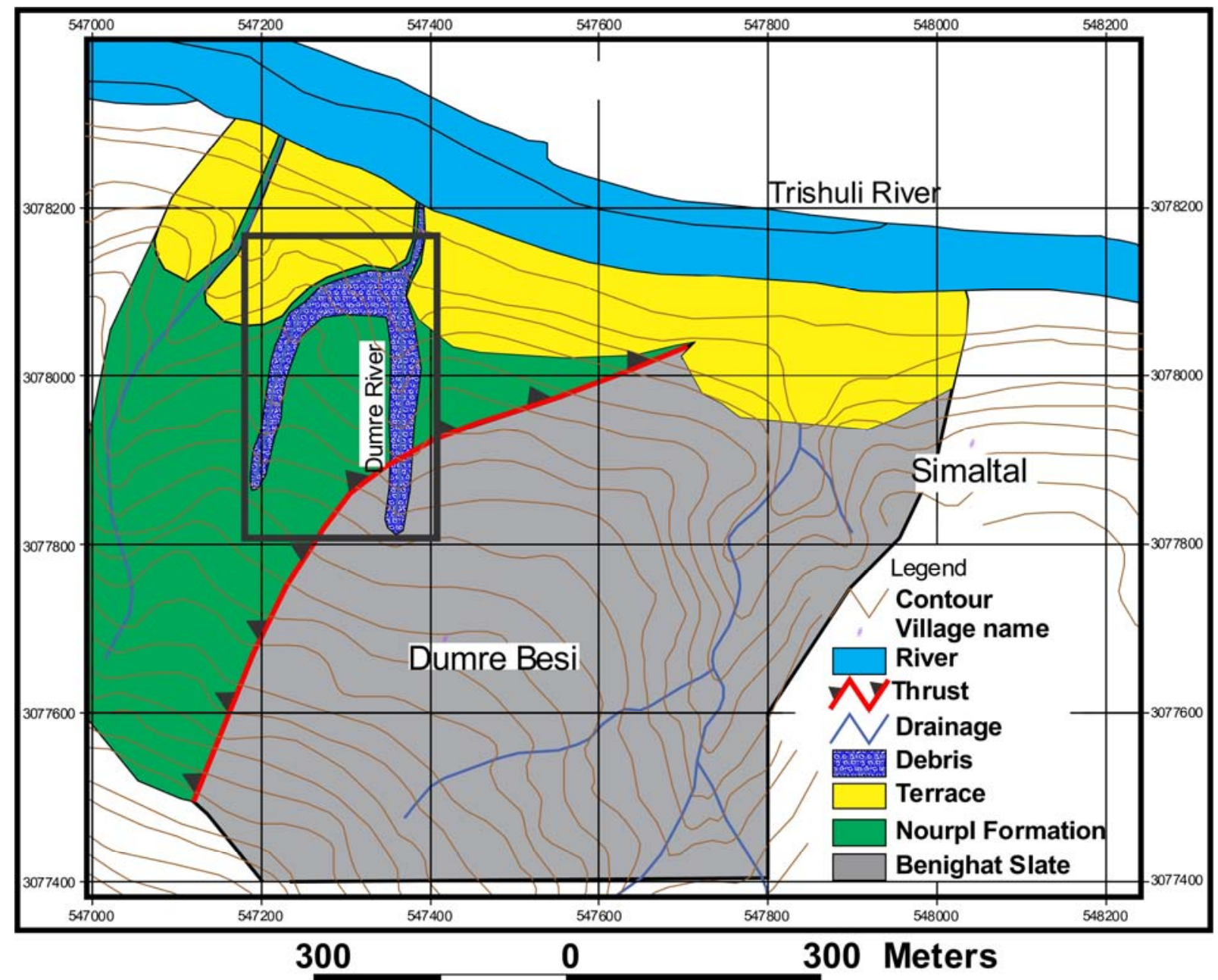

Fig. 2 Geological map of the landslide and its surrounding area 


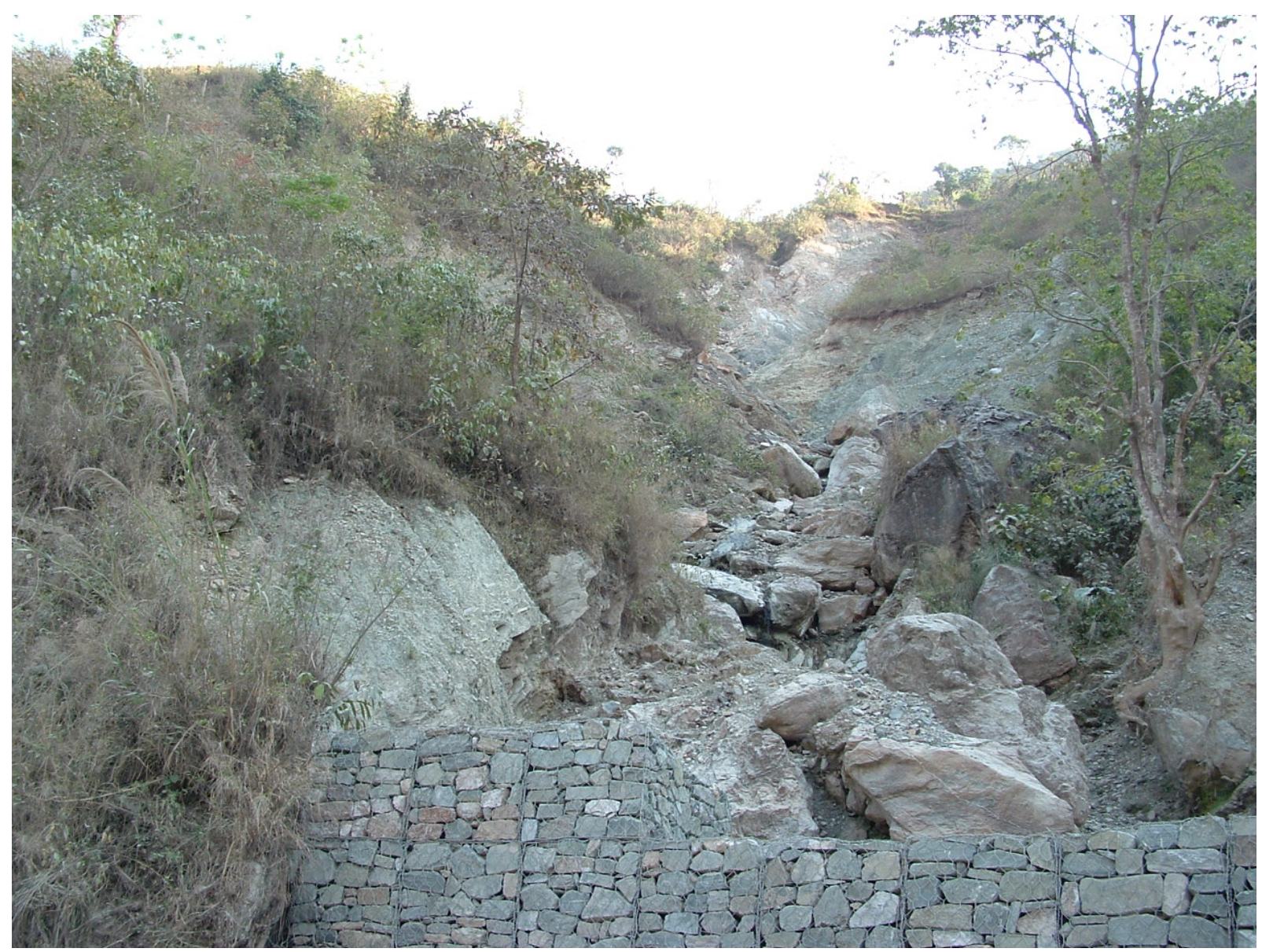

Fig. 3 Photograph showing the Dumre Besi landslide and its surrounding area, view towards south. Photograph is from the area incorporated in the box in Fig. 2 


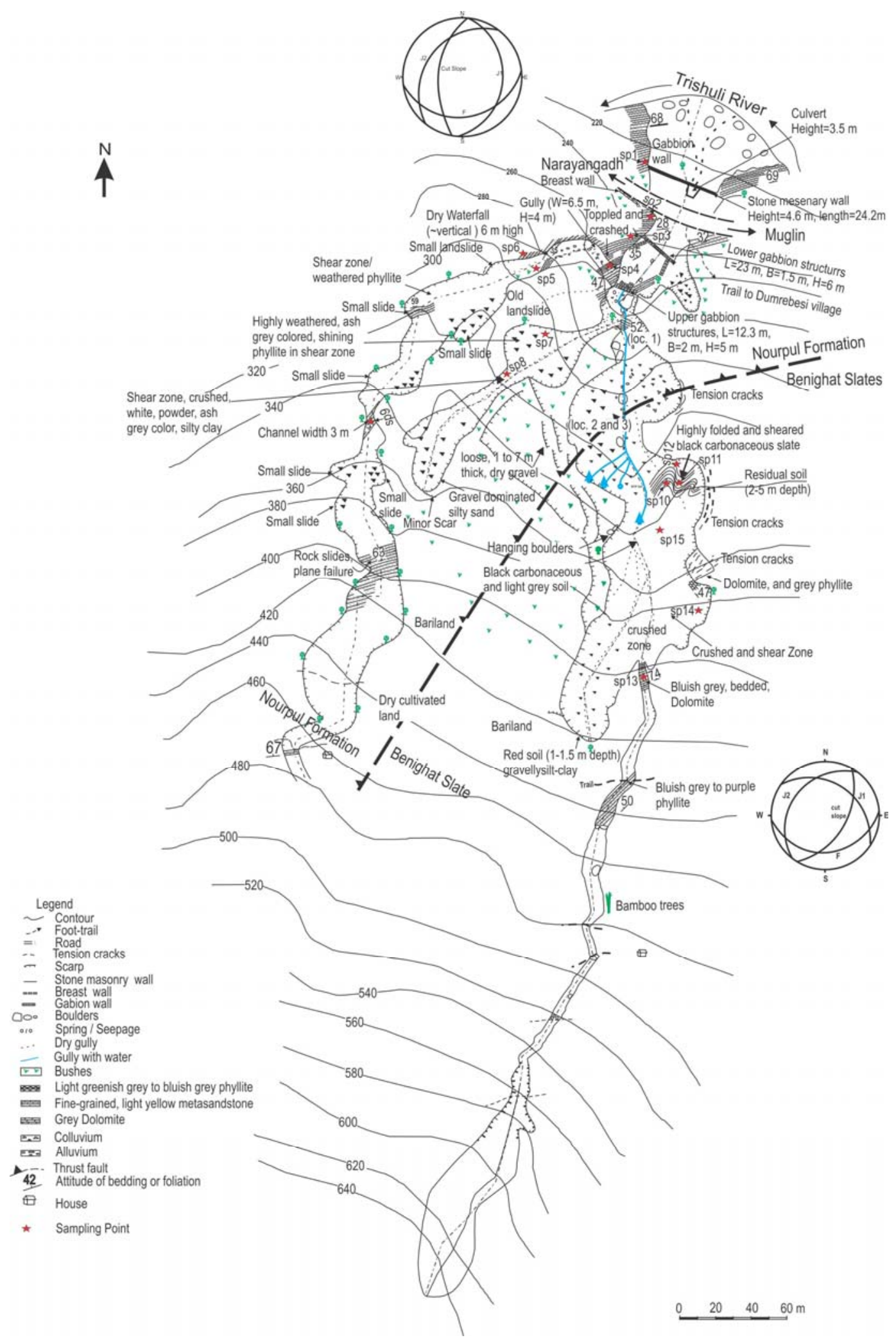

Fig. 4 Map showing the detailed features of the landslide of Dumre Besi 


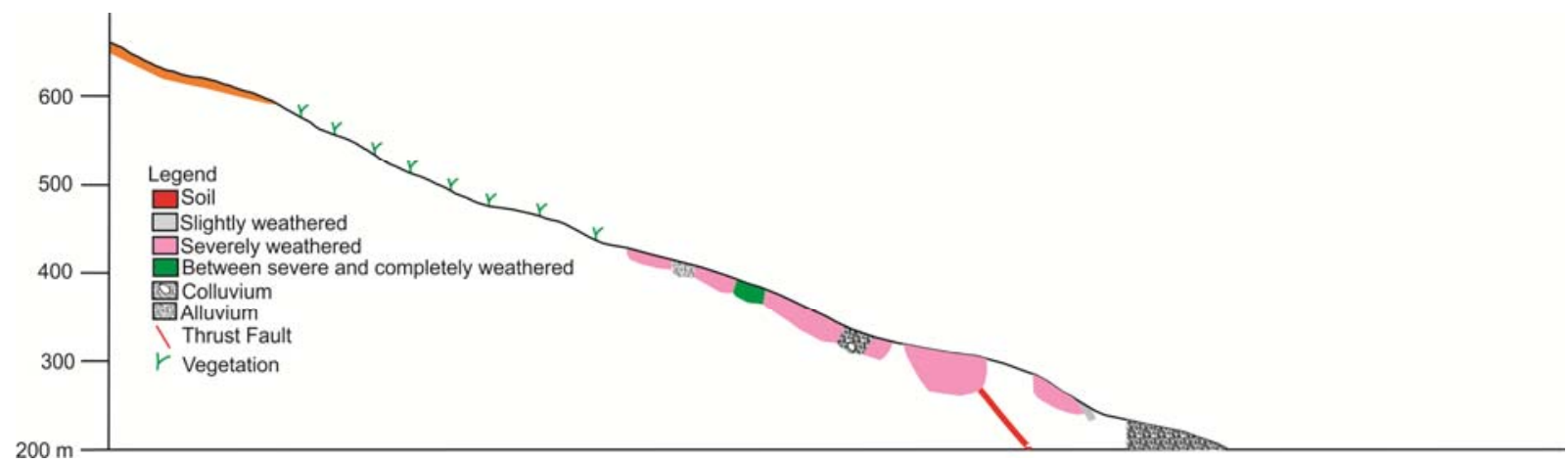

Fig. 5 Cross-section of the landslide 


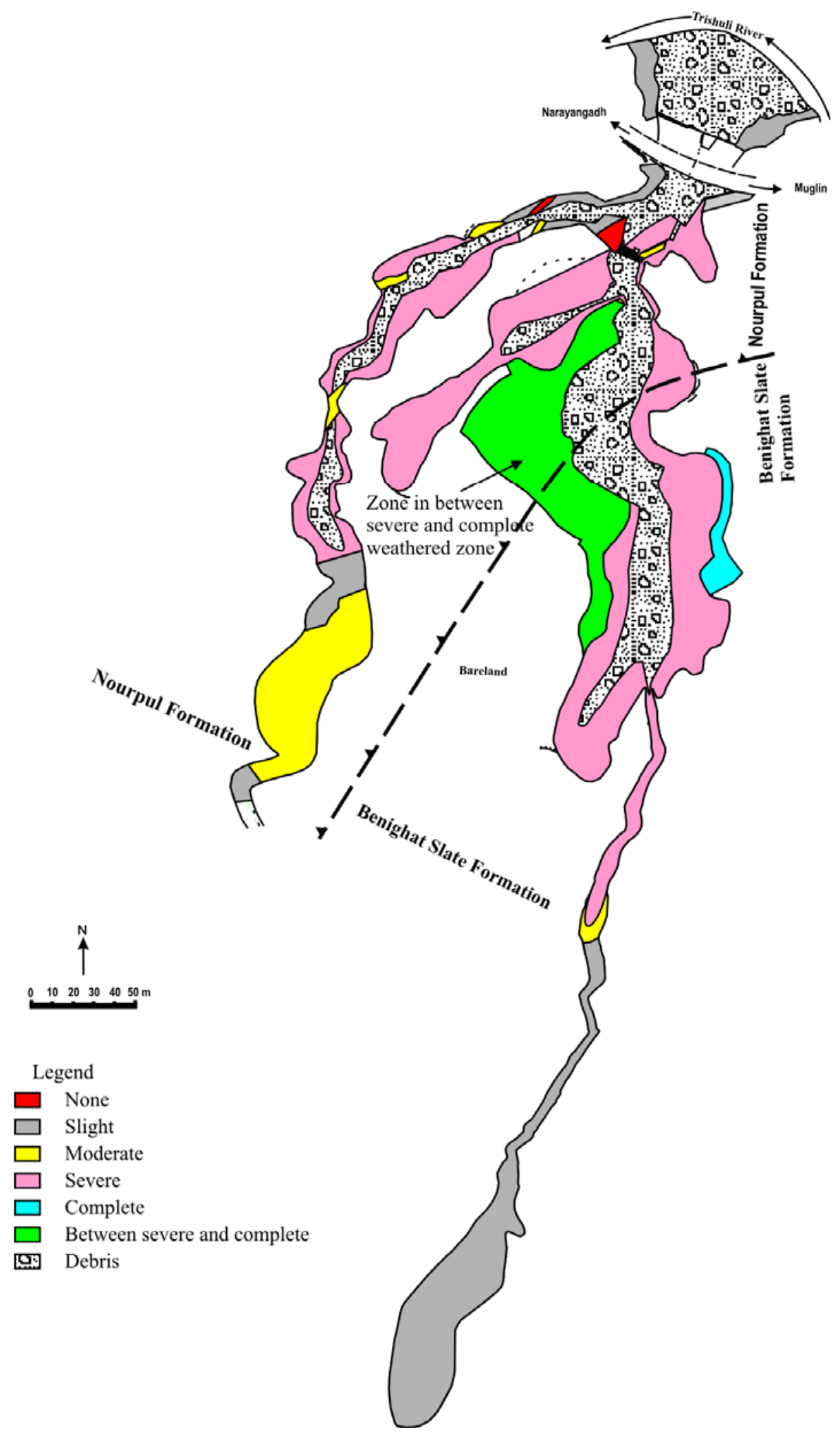

Fig. 6 Map showing the weathering of rocks in the landslide zone 


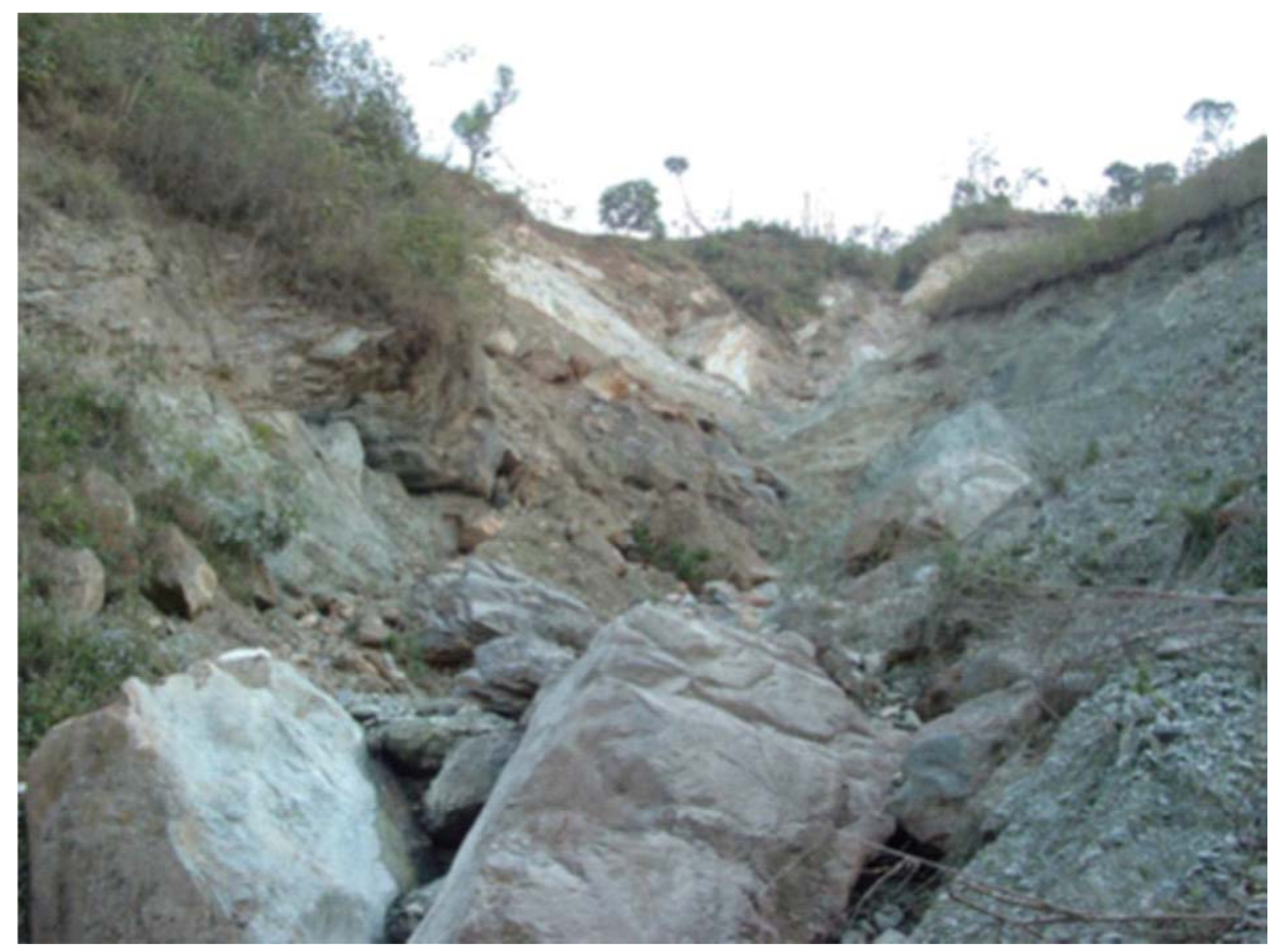

Fig. 7 Debris along the channel draining the landslide consists of boulders up to $7 \mathrm{~m}$ in diameter. View towards south (Location 1 in Fig. 4) 


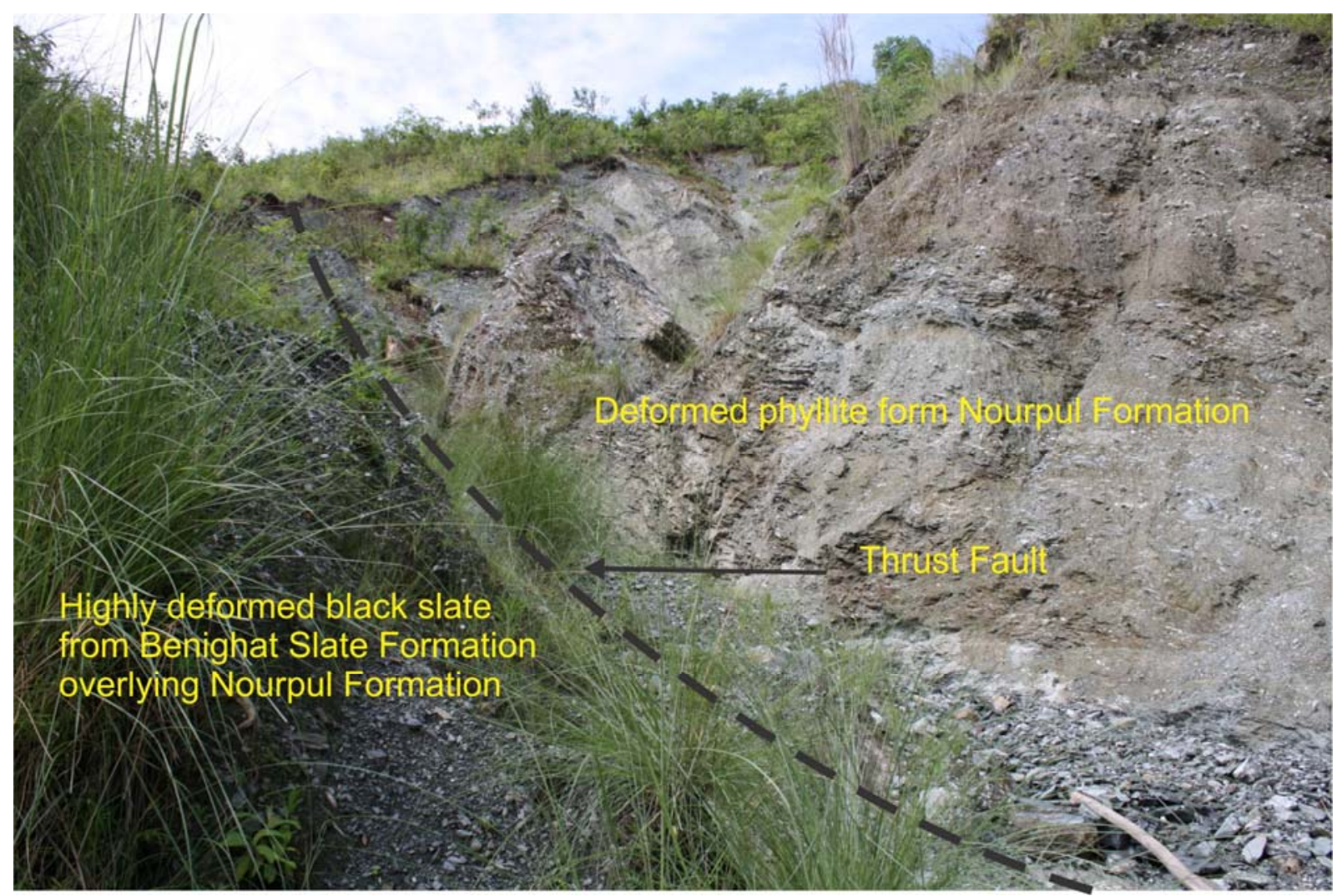

Fig. 8 Thick crushed zone developed along the thrust, view towards south (Location 2 in Fig. 4) 


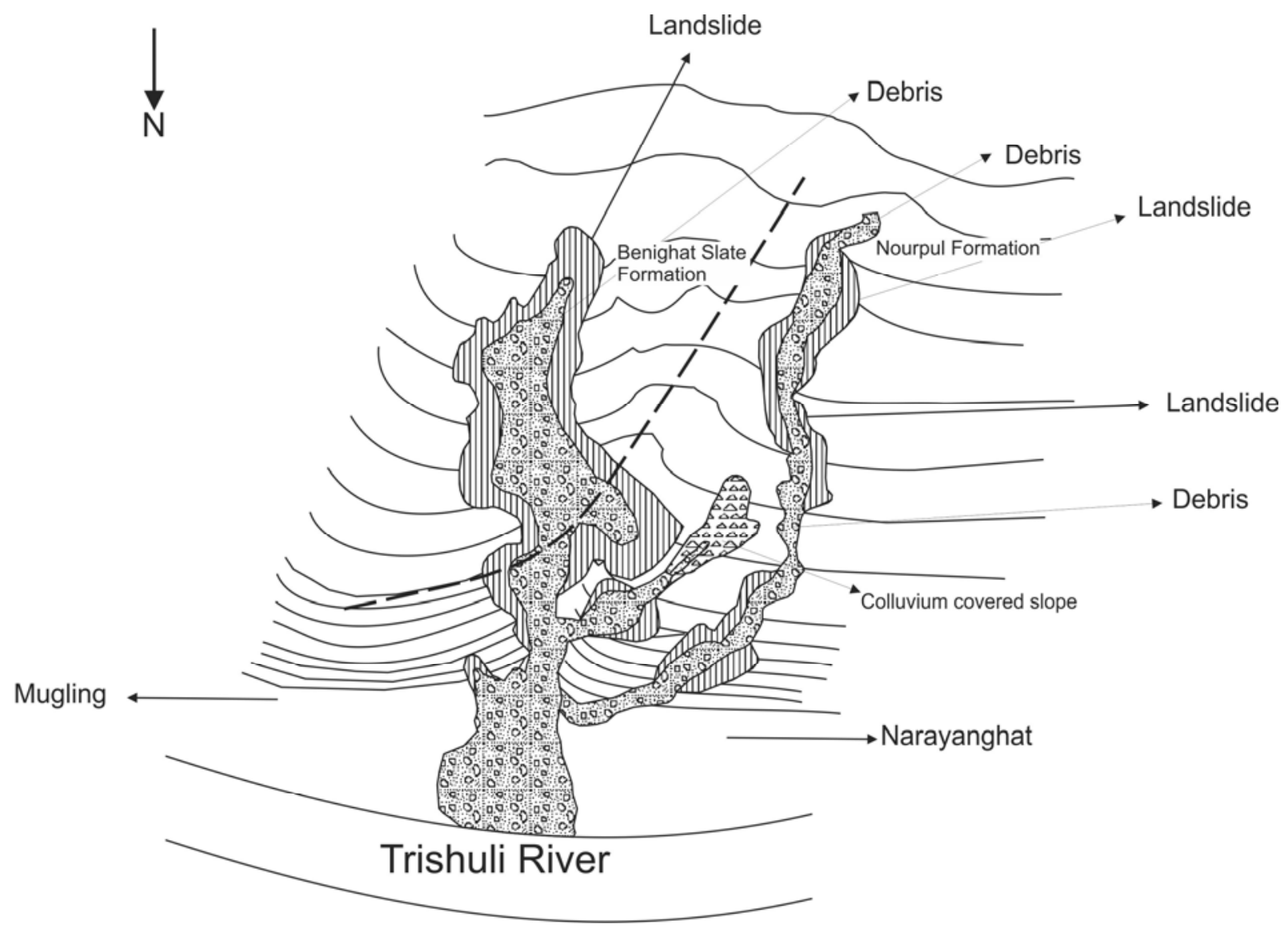

Fig. 9 Map showing the major sources of debris 

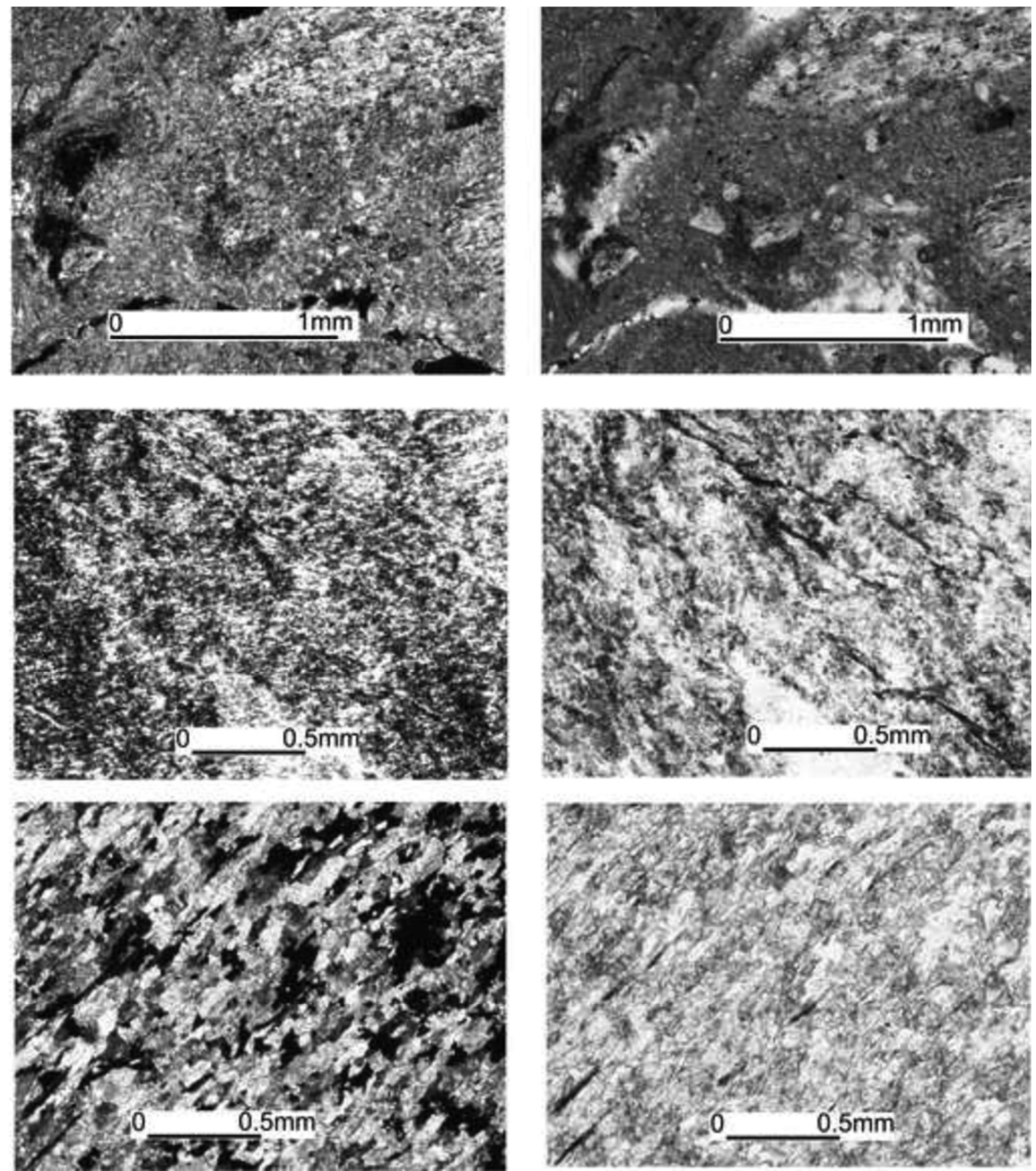

Fig. 10 Photomicrographs of different rock types from the landslide zone; both in cross nichols and plane polarized light. a Sp9: Severely weathered light grey phyllite from the thrust zone, many large and small crystals are found together; some crystals are angular. Many clay minerals are found here. b Sp12: Weathered black slate showing many cross-cutting quartz veins. These veins are discolored, indicating chemical weathering. The veins show at least two deformational phase. c Sp13: Well-developed cleavage plane in weathered dolomitic slate; many calcite and quartz crystals show preferred orientation 

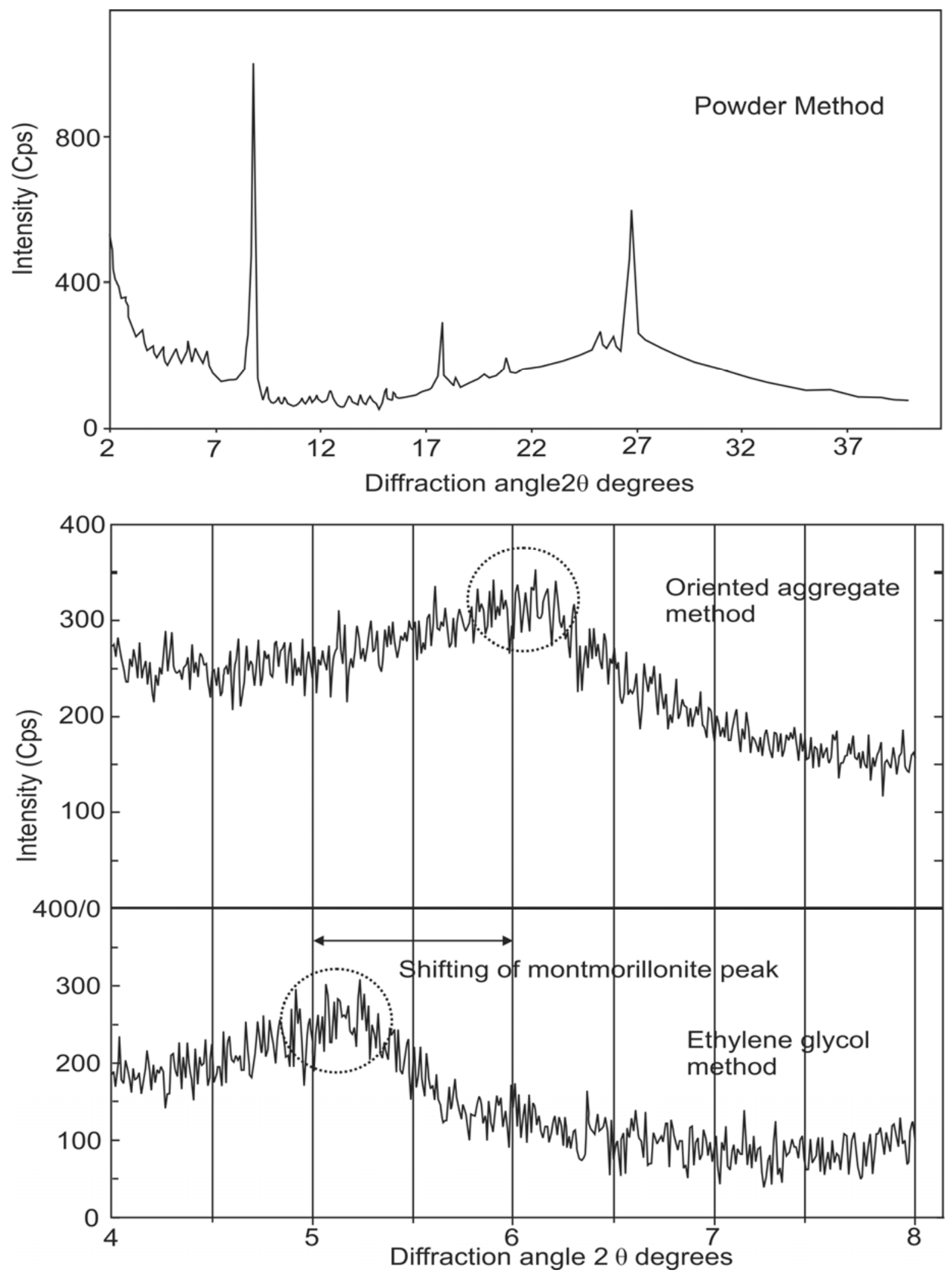

Fig. 11 XRD pattern of Sp8 (a) bulk sample, (b) oriented aggregate sample, and (c) ethylene glycol treated sample 

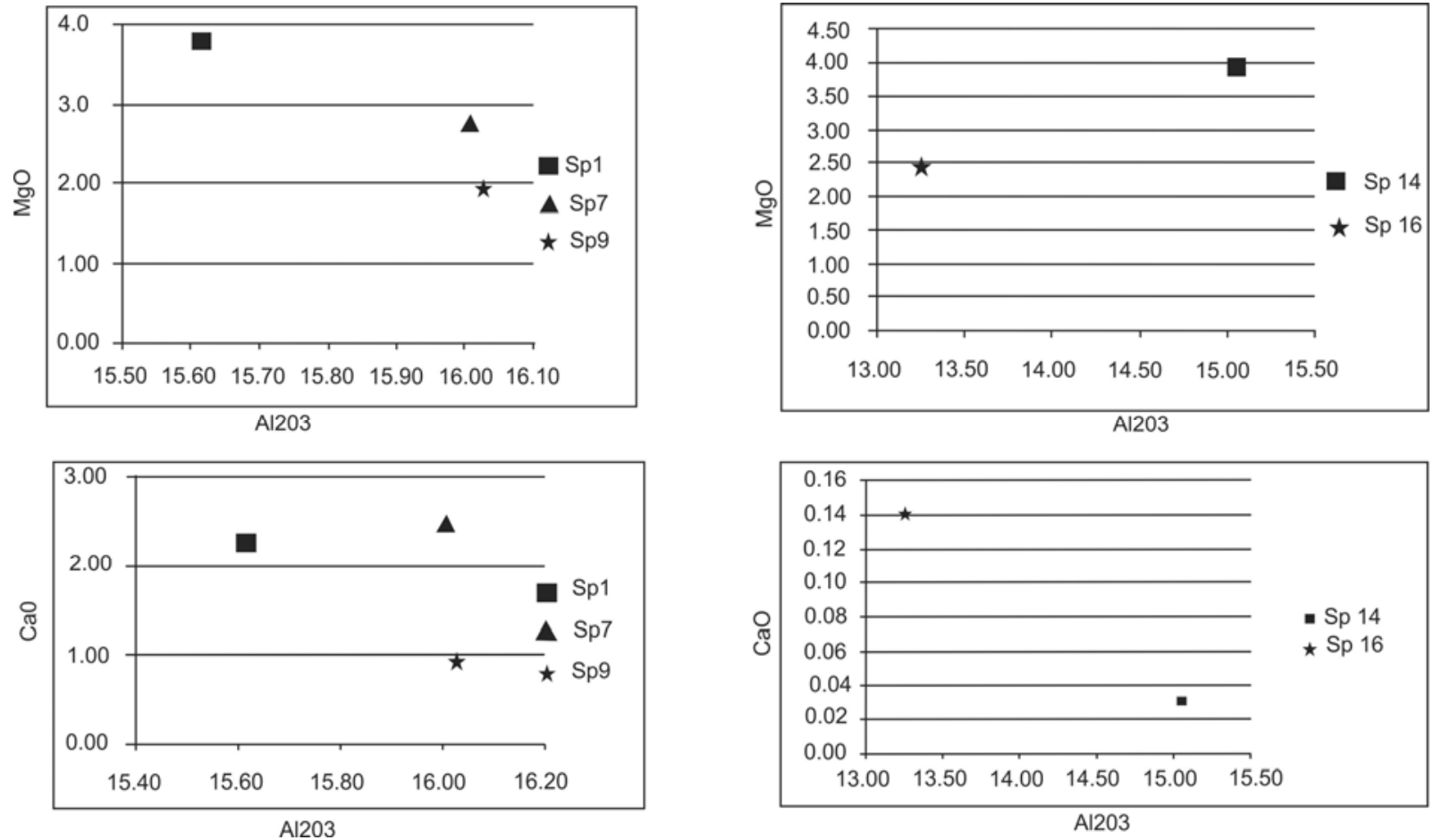

Fig. 12 Selected diagrams showing major element-Al2O3 variations

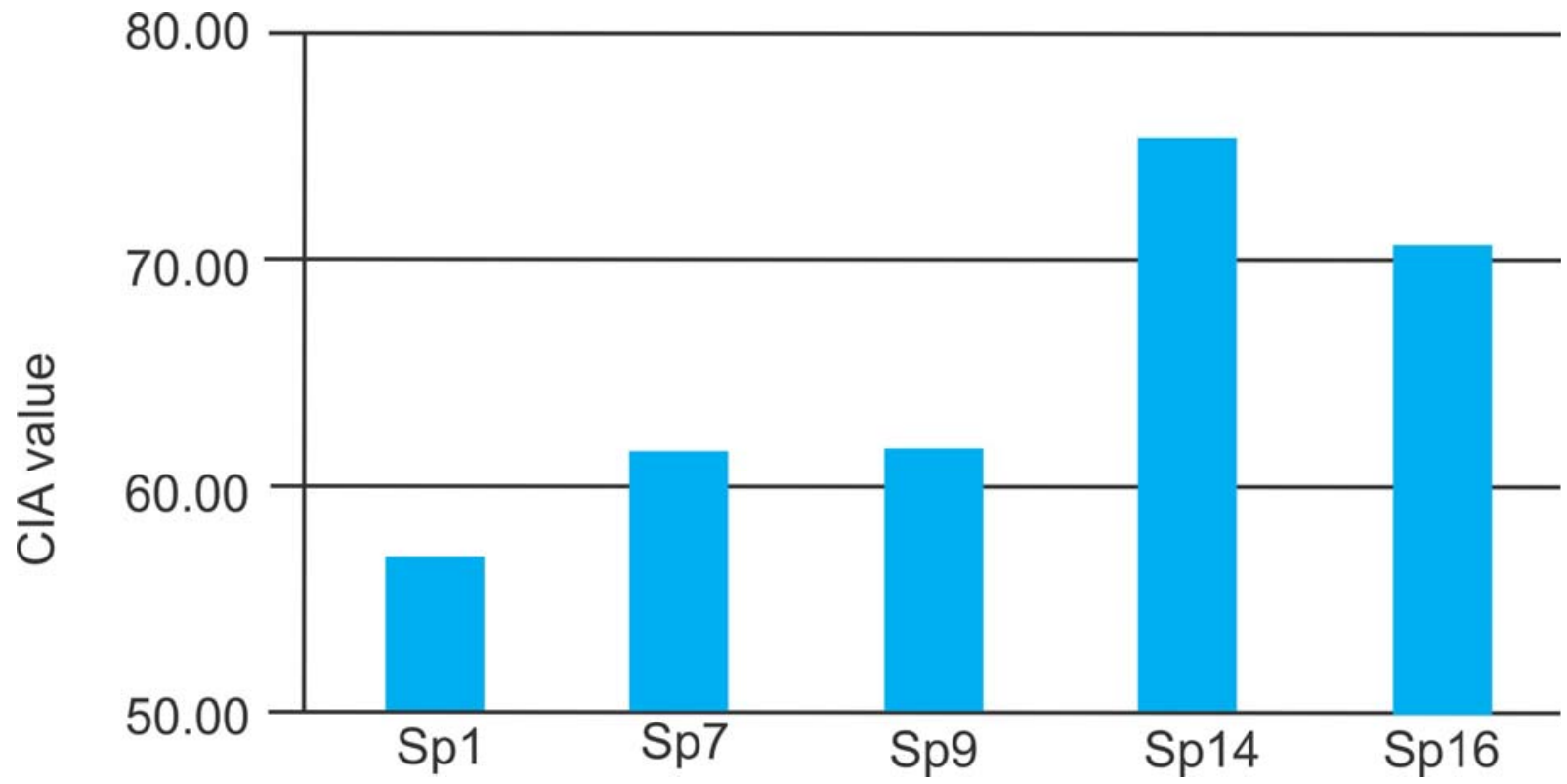

Fig. 13 Figure showing the Chemical Index of Alteration (CIA) plots of fresh and weathered rocks 